\title{
A dificuldade de aceitação
}

\section{The difficult to be accepted}

\section{La difficulté d'acceptation}

Alessandra Silva PINTO

\section{RESUMO}

Este depoimento tem por objetivo relatar as dificuldades encontradas para a aplicação de uma proposta de intervenção na qual a atividade pedagógica trata da cultura africana. Mostra como, embora vivamos em um país com raízes africanas, muito ainda se tem a aprender acerca destas culturas, incluindo a sua aceitação como identidade de nosso povo e como a educação ainda vem tratando este assunto embora o mesmo já deva fazer parte da grade curricular conforme lei promulgada.

Palavras-chave: Cultura africana, Educação, Resistência.

\section{ABSTRACT}

This testimony aims to relate the difficulties for the application of an intervention proposal in which the activity deals with the African culture. It is an example that, even we live in a country with African roots, there are many things that must be learned about these cultures, including its acceptance as identity of our people. It also shows as the education treats this subject even it is officially part of scholar curriculum according to promulgated law.

Index terms: African Culture, Education, Resistance.

\section{RÉSUMÉ}

Ce témoignage a pour objectif de démontrer les difficultés rencontrées concernant l'application d'une proposition d'intervention de les cultures africaines. Ce qu'on a remarqué c'est que malgré le fait d'habiter dans un pays ayant des racines africaines, il y a encore beaucoup à apprendre, y compris son acceptation et surtout, comment l'éducation réagit face à ces problèmes, malgré les statuts pédagogiques brésiliens et l'obligation de cet apprentissage dans les écoles, par la loi brésilienne.

Mots-clés: Culture Africaine, Éducation, Résistance. 
Durante o mês de maio de 2008, realizei, em uma escola de ensino fundamental do município de São Paulo, um período de observação de sala, solicitado pela professora Nilce da Silva, já que participei de "espaço de criação" por ela desenvolvido e coordenado.

Depois de feita esta observação, especialmente sobre as relações raciais existentes em sala de aula, a referida professora nos pediu a elaboração de uma intervenção em sala de aula da escola de um tema que tenha sido discutido durante nossos encontros acerca do mundo lusófono.

Num primeiro momento, a tarefa parecia não ser tão complicada e, também, aparentemente, não haveria problema em aplicá-la em sala de aula, uma vez que trataríamos da alfabetização em países de língua oficial portuguesa, majoritariamente, pertencentes ao continente africano.

As idéias foram muitas devido ao vasto material apresentado no referido "espaço de criação", incluindo os seminários apresentados pelos nossos colegas de estudo que nos mostraram muitas características culturais destes diversos países que poderiam, muito facilmente, ser apresentados para alunos do ensino fundamental.

Iniciada a proposta de observação, conversei com a coordenação da escola a respeito da aplicação de uma atividade que envolvesse a citada temática em sala de aula. A princípio, a proposta foi aceita com a condição de que a atividade fosse apresentada para avaliação da coordenação antes de ser aplicada. Até este momento, não percebi nenhum problema quanto a esta exigência.

Durante alguns dias de permanência na escola, além da observação em sala de aula, tentei conhecer um pouco mais os alunos e a professora a fim de elaborar uma atividade que fosse interessante para ambos e que contasse com a participação de todos. 
Após esta observação, optei por apresentar uma lenda de GuinéBissau que trata da origem do tambor aficano. Nesta intervenção, a intenção era mostrar às crianças que existem em outros países, além do Brasil, pessoas que também falam a Língua Portuguesa e que apesar de serem países diferentes e distantes, têm muitas semelhanças com o nosso país, principalmente nos aspectos culturais. Com a leitura desta lenda, poderia ser trabalhada a comparação com as diversas lendas contadas em nosso país e mostrar que existem muitas semelhanças entre elas quando se trata do mito. Juntamente, poderia ser mostrado aos alunos o quanto o nosso país é influenciado pelas culturas africanas tanto na comida, na escrita, na música, etc. No final da atividade, seria proposto aos alunos que desenhassem o tambor africano da maneira que imaginassem ser o instrumento após terem escutado a lenda e, posteriormente, eu mostraria uma figura de tambor "brasileiro" para compará-lo com os instrumentos existentes em na GuinéBissau.

Ao criar esta proposta, tive como base a rotina da professora com os alunos para não desviar muito da proposta pedagógica para a sala. Optei por fazer a leitura da lenda, pois notei que fazia parte da rotina da professora da sala, ler para os alunos, pelo menos três vezes por semana, uma fábula que tivesse uma mensagem a ser trabalhada por eles quer em produção de textos, quer em desenhos ou discussão em sala sobre o tema.

Ao apresentar a proposta, qual não foi a minha surpresa quando a coordenadora respondeu que não seria possível a intervenção. Quando questionada sobre a impossibilidade da aplicação, respondeu-me que a professora já havia preparado uma proposta curricular para a sala e que uma intervenção de quem quer que fosse, iria atrapalhar o desenvolvimento do trabalho proposto pela professora.

Infelizmente, não foi essa a interpretação que tive mediante tal 
negativa. Considerei que a aplicação da atividade não foi possível por se tratar da apresentação de uma cultura "diferente". Coloco tal palavra entres aspas, pois entendo que não se trata de uma cultura diferente e sim da nossa cultura, ou melhor, da parte negada da nossa cultura já que é influência do povo africano. Basta olhar as pessoas, a grande maioria tem traços africanos e as que aparentemente não apresentam estes traços físicos, certamente carregam esta característica em seu DNA.

Infelizmente, entendo que a escola brasileira, a educação está deixando muito a desejar no que se trata de trabalhar as culturas africanas com seus alunos. Embora exista uma lei que obrigue a apresentação e o trabalho envolvendo este tema em sala de aula, o que se percebe é que as culturas africanas não alcançaram o devido tratamento como disciplina em sala de aula, ficando apenas como uma data comemorativa como, por exemplo, o Dia da Consciência Negra. Ou seja, do meu ponto de vista, nega-se claramente as culturas africanas em nosso país.

O que me resta de consolo é que esta negação não é regra e que existem escolas que tratam este assunto com seriedade, prova disto foi a conversa que tivemos no âmbito do "espaço de criação" a respeito das outras experiências de intervenção em sala de aula em que muitos colegas obtiveram sucesso em suas propostas e práticas. 


\section{Autora}

\section{Alessandra Silva Pinto}

Graduanda em Pedagogia, Faculdade de Educação da Universidade de São Paulo.

Contato: alessandra.pinto@usp.br

\section{Como citar este depoimento:}

Pinto. Alessandra Silva. A dificuldade de aceitação. Revista ACOALFAplp: Acolhendo a Alfabetização nos Países de Língua portuguesa, São Paulo, ano 3, n. 6, 2009. Disponível em: <http://www.acoalfaplp.net>. Publicado em: março 2009.

Recebido em junho de 2008./Aprovado em julho de 2008.

$$
\text { escolar. }
$$

